\title{
УДК 658:657.471.1
}

\section{УПРАВЛІННЯ ВИТРАТАМИ ГОСПОДАРСЬКОЇ ДІЯЛЬНОСТІ ПІДПРИЕМСТВА}

\section{Олена Ковальова}

\author{
Харківський національний аграрний університет імені В. В. Докучаєва, \\ Харків, Україна
}

\begin{abstract}
Резюме. Визначено сутність управління витратами підприємства. Розроблення ефективної системи управління витратами є важливим завданням і для аграрних підприємств. Зважаючи на це, було проведено комплексний аналіз витрат досліджуваного підприємства та обтрунтовано основні напрями управління витратами підприємства. Визначено основні завдання системи управління витратами: здійснення контролю за ходом господарської діяльності підприємства; виявлення тендениій змін рівня, обсягу та структури витрат на обсяг виробництва та одиницю продукиї; збір, аналіз інформаиії про витрати; нормування, планування витрат у розрізі елементів, виробничих підрозділів і видів продукцї; пошуку резервів економії ресурсів і оптимізаиї витрат. Дослідження системи управління витратами дало можливість встановити, щчо вона має функціональний та організачійний аспекти $і$ включає такі організаиійні підсистеми: пошук і виявлення чинників економії ресурсів; нормування витрат ресурсів; планування витрат за їхніми видами; облік та аналіз витрат; стимулювання економії ресурсів $і$ зниження витрат. Створення ефективної системи управління витратами передбачає систематичний моніторинг фактичних витрат та їх поведінки під дією як внутрішніх, пак і зовнішніх факторів, прийняття рішення щзодо покращення структури собівартості продукиії тощь. 3 метою підвищення ефективності управління витратами запропоновано впровадження комп'ютеризаиї витрат на базі використання сучасних технічних засобів збирання, передавання, накопичення, опрацюювання та використання інформаиї на всіх стадіях життєвого ичилу продукиії (послуги). У результаті підвишується якість норм $i$ нормативів за рахунок комп'ютеризації розрахунків $i$ їх технічної обтрунтованості. Зростає оперативність і точність обліку змін норм і нормативів, причин, щуо їх зумовили, зменшення втрат через недоробки при технічній підготовиі виробництва. Завдяки комп'ютеризаиії витрат встановлюється раціональний їх рівень, а, отже, досягається раціональне використання матеріальних і трудових ресурсів підприсмства.
\end{abstract}

Ключові слова: витрати, управління витратами, система управління витратами, комп 'ютеризація витрат.

\section{UDC 658:657.471.1}

\section{THE ENTERPRISE ECONOMY COST MANAGEMENT}

\section{Olena Kovalyova}

\author{
Kharkiv National Agrarian University named after V. V. Dokuchaev, \\ Kharkiv, Ukraine
}

Summary. The essence of enterprise cost management is defined in his paper. Development of the effective cost management system is also an important task for agricultural enterprises. Considering this, the comprehensive cost analysis of the investigated enterprise was carried out and the basic directions of the enterprise cast management were substantiated. The main tasks of the cost management system are defined: control over the course of the enterprise business activity; identification of trends in the level changes, volume and cost structure of production and output unit; collecting, analyzing of cost information; rationing, cost planning in 
terms of elements, production units and types of products; search of reserves for to resources saving and cost optimization. The investigation of the cost management system made it possible to establish that it has functional and organizational aspects and includes the following organizational subsystems: search and identification of resources saving factors; rationing of resources costs; cost planning by type; cost accounting and analysis; stimulating resource savings and reducing costs. Creation of effective cost management system involves systematic monitoring of actual costs and their behavior under the influence of both internal and external factors, decision making concerning the improvement of the products cost structure etc. In order to increase the cost management efficiency, it is proposed to introduce the cost computerization based on the use of modern technical means of collecting, transmitting, accumulating, processing and using information at all stages of the product (service) life cycle. It results in the quality of norms and regulations improvement due to the computerization of calculations and their technical justification. Efficiency and accuracy of accounting of changes in norms and regulations, the reasons that caused them increase, losses due to shortcomings in the production technical preparation decrease. By means of costs computerization their rational level is determined, and thus, the rational use of material and labor resources of the enterprise is ensured.

Key words: costs, cost management, cost management system, cost computerization.

Постановка проблеми. У ринковій економіці головною засадою існування кожного окремого товаровиробника вважається його конкурентоспроможність. Одним із центральних моментів при цьому є підвищення ефективності й оптимізації витрат суб'єктів господарювання. Це потребує розроблення принципів і методів їх формування iз застосуванням новітніх економічних технологій. Витрати підприємства залежать від рівня та ступеня використання ресурсів підприємства, також вони є матеріальним віддзеркаленням відносин суб'єктів господарювання. Актуальність вирішення зазначених проблем в останній час ще більш загострюється. Це зумовлено тим, що останніми роками відбувалося постійне зростання цін на сировину та матеріали. Отже, одним із основних джерел підвищення прибутковості діяльності підприємств $\epsilon$ оптимізація витрат й ефективність управління ними.

Аналіз останніх досліджень і публікацій. Фундаментально-теоретичні розробки в області формування витрат і теорії вартості були здійснені у працях таких учених, як У. Петті, Ф. Кене, А. Сміт, К. Маркс, Д. Рікардо, А. Маршалл, К. Менгер, Ф. Візер, Е. Бем-Баверк, Д. Кейнс, Д. Хікс та ін. Питання, пов'язані з теорією та практикою формування витрат, підвищення їх ефективності на сучасному етапі розвитку сільськогосподарського виробництва знайшли своє відображення в наукових працях таких учених, як В. Г. Андрійчук, I. М. Бойчик, О. М. Варченко, М. Г. Грещак, А. С. Даниленко, С. І. Дем'яненко, М. Я. Дем'яненко, О. С. Коцюба, П. Т. Саблук, В. Я. Месель-Веселяк, П. М. Макаренко, О. В. Олійник, І. В. Охріменко, Б. Й. Пасхавер, Д. В. Шиян, О. М. Шпичак, О. Г. Шпикуляк, О. В. Шубравська та ін. Не зважаючи на всю важливість здійснених досліджень, окремі аспекти проблеми формування витрат у сільськогосподарських підприємствах потребують подальшого розгляду. Зокрема, це стосується уточнення класифікації витрат і понятійного апарату, впливу розміру підприємств, природно-кліматичних умов України на рівень та ефективність витрат, взаємозв'язку прибутковості виробництва 3 інтенсивністю й розміром підприємства тощо. Актуальність роботи зумовлюється проведенням подальших наукових досліджень управління витратами сільськогосподарської продукції й обгрунтування на цій основі стратегічних перспектив.

Метою дослідження $є$ розроблення пропозицій щодо вдосконалення управління витратами в господарській діяльності підприємства.

Постановка завдання. Для досягнення поставленої мети визначено такі наукові завдання: здійснити комплексний аналіз витрат досліджуваного підприємства; обгрунтувати основані напрями управління витратами на підприємстві; запропонувати 
напрями удосконалення управління витратами, що забезпечує оптимальний рівень собівартості продукції підприємства.

Виклад основного матеріалу. Під управлінням витратами слід розуміти процес цілеспрямованого формування витрат за її видами, місцями і носіями при постійному контролі й стимулюванні їх зменшення, що $є$ важливою функцією економічного механізму будь-якого підприємства. Основною метою функціонування сільськогосподарського підприємства $\epsilon$ забезпечення його стійкого розвитку, що можливо досягти за умови постійного пошуку та реалізації заходів щодо підвищення рівня економічної ефективності господарювання.

Одним із важливих показників, який впливає на ефективність виробничогосподарської діяльності підприємства даної галузі чи його структурних підрозділів, $\epsilon$ собівартість продукції, що відображає поточні витрати, пов'язані з виробництвом та реалізацією сільськогосподарської продукції. Тому питання визначення собівартості окремих видів продукції підприємств галузі сільського господарства, іiі планування та аналізу з метою пошуку та реалізації заходів щодо зниження рівня витрат потребують постійного та першочергового вивчення, оскільки від цього значною мірою залежать результати діяльності самого підприємства, його економічний та соціальний розвиток [1].

За даними табл. 1 визначимо зміну обсягу витрат на виробництво продукції в АФ «Надія» ТОВ протягом 2016-2018 рр. і порівняємо їх значення.

\section{Таблиця 1}

Обсяг витрат на виробництво продукції в АФ «Надія» ТОВ Чугуївського району Харківської області, 2016-2018 рр., грн./ц

Table 1

Volume of production costs at Ltd. «Nadiya» $\mathrm{AB}$ of Chuguev district, Kharkiv region, 2016-2018, UAH/c

\begin{tabular}{|c|c|c|c|c|}
\hline Культури & 2016 p. & 2017 p. & 2018 p. & 2018 p. до 2016 p., \% \\
\hline Зернові і зернобобові & 148,72 & 200,86 & 228,76 & 153,8 \\
\hline Соняшник & 203,31 & 304,22 & 399,9 & 196,7 \\
\hline Молоко & 374,17 & 435,47 & 717 & 191,6 \\
\hline Приріст живої маси ВРХ & 4161,96 & 7126,76 & 7850 & 188,6 \\
\hline
\end{tabular}

Обсяг витрат на 1 ц продукції зріс у 2018 р. порівняно з попередніми роками. На 88,6\% зросли витрати на 1 ц на приріст живої маси ВРX, на 91\% - на 1 ц при виробництві молока, на 96,7\% - на 1 ц соняшнику і на 53,8\% - на виробництві зернових i зернобобових.

Важливо також зосередити увагу на структурі витрат за економічними елементами. Таке дослідження дозволить визначити питому вагу кожного економічного елемента, а також частки живої та уречевленої праці у загальній сумі витрат на виробництво. Детальний аналіз структури витрат та розрахунок показників наведено в табл. 2.

Аналіз зміни витрат по елементах показав, що у звітному періоді спостерігається зниження матеріальних витрат у рослинництві, а у тваринництві - збільшення. Також i за всіма іншими елементами відбулося коливання у бік зменшення й збільшення показників як у рослинництві, так і тваринництві. Витрати на оплату праці в структурі витрат у рослинництві становили 4,1\% у 2017 р. і 5,1\% - в 2018 р. У тваринництві - 9,2\% 
і 8,2\% відповідно по роках, тоді як у розвинених закордонних країнах заробітна плата в структурі собівартості продукції становить 30-50\%.

Таблиця 2

Аналіз структури витрат на виробництво в АФ «Надія» ТОВ Чугуївського району Харківської області, 2017-2018 pp.

Table 2

Analysis of the structure of production costs at Ltd. «Nadiya» AB of Chuguev district, Kharkiv region, 20172018

\begin{tabular}{|c|c|c|c|c|c|c|}
\hline \multirow[b]{2}{*}{ Показник } & \multicolumn{6}{|c|}{ Елементи витрат } \\
\hline & $\begin{array}{c}\text { Матеріальні } \\
\text { витрати }\end{array}$ & $\begin{array}{c}\text { Витрати } \\
\text { на } \\
\text { оплату } \\
\text { праці }\end{array}$ & $\begin{array}{c}\text { Відрахування } \\
\text { на соц. } \\
\text { заходи }\end{array}$ & Амортизація & $\begin{array}{c}\text { Інші } \\
\text { операційні } \\
\text { витрати }\end{array}$ & Разом \\
\hline \multicolumn{7}{|c|}{$2017 \mathrm{p}$. } \\
\hline \multicolumn{7}{|c|}{ Рослинництво, } \\
\hline тис. грн. & 24847 & 1250 & 269 & 1089 & 3410 & 30865 \\
\hline$\%$ & 80,5 & 4,1 & 0,9 & 3,5 & 11,0 & 100,0 \\
\hline \multicolumn{7}{|c|}{ Тваринництво, } \\
\hline тис. грн. & 19817 & 2179 & 468 & 1169 & - & 23633 \\
\hline$\%$ & 83,8 & 9,2 & 2,0 & 5,0 & - & 100,0 \\
\hline \multicolumn{7}{|c|}{$2018 \mathrm{p}$} \\
\hline \multicolumn{7}{|c|}{ Рослинництво, } \\
\hline тис. грн. & 24044 & 1770 & 380 & 21,0 & 8942 & 34756,0 \\
\hline$\%$ & 69,18 & 5,09 & 4,25 & 0,06 & 25,73 & 100 \\
\hline \multicolumn{7}{|c|}{ Тваринництво, } \\
\hline тис. грн. & 33638 & 4294 & 712 & 311 & 14271 & 52203 \\
\hline$\%$ & 64,44 & 8,23 & 1,36 & 0,60 & 27,34 & 100 \\
\hline \multicolumn{7}{|c|}{ Відхилення 2018 р. від 2017 р. } \\
\hline \multicolumn{7}{|c|}{ Рослинництво, } \\
\hline тис. грн. & -803 & 520 & 111 & -1068 & 5532 & 3891 \\
\hline$\%$ & $-20,64$ & 13,36 & 2,85 & $-27,45$ & 142,17 & 100 \\
\hline \multicolumn{7}{|c|}{ Тваринництво, } \\
\hline тис. грн. & 13821 & 2115 & 244 & -858 & - & 28570 \\
\hline$\%$ & 48,38 & 7,40 & 0,85 & $-3,00$ & - & 100 \\
\hline
\end{tabular}

Далі важливо детальніше дослідити структуру виробничої собівартості у розрізі окремих видів сільгосппродукції. Аналіз даних табл. 3 свідчить, що виробнича собівартість пшениці зросла за останній досліджуваний рік на 52,2\% порівняно з 2016 р. Прямі матеріальні витрати за весь період були майже стабільним і у загальній структурі витрат їх частка перевищує 80\%. 


\section{Таблиця 3}

Структура виробничої собівартості пшениці в АФ «Надія» ТОВ Чугуївського району Харківської області, 2016-2018 pp.

Table 3

Structure of wheat production cost at Ltd. «Nadiya» AB of Chuguev district, Kharkiv region, 2016-2018

\begin{tabular}{|l|c|c|c|c|c|c|}
\hline \multirow{2}{*}{\multicolumn{1}{|c|}{ Показник }} & \multicolumn{2}{c|}{$2016 \mathrm{p}}$. & \multicolumn{2}{c|}{$2017 \mathrm{p.}$} & \multicolumn{2}{c|}{$2018 \mathrm{p.}$} \\
\cline { 2 - 7 } & $\begin{array}{c}\text { Тис. } \\
\text { грн. }\end{array}$ & $\%$ & $\begin{array}{c}\text { Тис. } \\
\text { грн. }\end{array}$ & $\%$ & $\begin{array}{c}\text { Tис. } \\
\text { грн. }\end{array}$ & $\%$ \\
\hline \multicolumn{1}{|c|}{2} & 3 & 4 & 5 & 6 & 7 \\
\hline $\begin{array}{l}\text { Виробнича собівартість } \\
\text { усього, тис. грн. }\end{array}$ & 3652,0 & 100 & 3540,0 & 100 & 5558,0 & 100 \\
\hline Прямі матеріальні витрати & 3021,0 & 82,72 & 3019,0 & 85,28 & 3215,0 & 57,84 \\
\hline У т.ч. & & & & & & \\
\hline $\begin{array}{l}\text { Насіння та посадковий } \\
\text { матеріал }\end{array}$ & 419,0 & 11,47 & 321,0 & 9,07 & 405,0 & 7,29 \\
\hline Мінеральні добрива & 954,0 & 26,12 & 1513,0 & 42,74 & 2308,0 & 41,53 \\
\hline ПММ & 557,0 & 15,25 & 469,0 & 13,25 & 130,0 & 2,34 \\
\hline Решта матеріальних витрат & 1091,0 & 29,87 & 716,0 & 20,23 & 372,0 & 6,69 \\
\hline $\begin{array}{l}\text { Прямі витрати на оплату } \\
\text { праці }\end{array}$ & 262,0 & 7,17 & 229,0 & 6,47 & 9,0 & 0,16 \\
\hline $\begin{array}{l}\text { Інші прямі витрати та зага- } \\
\text { льновиробничі витрати - } \\
\text { усього }\end{array}$ & 369,0 & 10,10 & 292,0 & 8,25 & 2334,0 & 41,99 \\
\hline $\begin{array}{l}\text { У т.ч. амортизація } \\
\text { необоротних активів }\end{array}$ & 274,0 & 7,50 & 286,0 & 8,08 & 2,0 & 0,04 \\
\hline $\begin{array}{l}\text { Відрахування на соціальні } \\
\text { заходи }\end{array}$ & 95,0 & 2,60 & 6,0 & 0,17 & - & - \\
\hline $\begin{array}{l}\text { Решта ін. прямих та } \\
\text { загальновиробничих витрат }\end{array}$ & - & - & - & - & 2332,0 & 41,96 \\
\hline
\end{tabular}

На насіння та посадковий матеріал було витрачено найбільше у 2016 р., а на паливно-мастильні матеріали - 2018 р. Витрати на мінеральні добрива мають стрімку тенденцію до зростання за весь досліджуваний період. Прямі витрати на оплату працю поступово зростали, окрім 2018 р. За останній рік дослідження сума (а, відповідно, і частка) витрат на оплату праці суттєво скоротилась і склала у загальній структурі витрат лише $0,16 \%$. Щодо інших витрат і загальновиробничих, то вони у 2018 р. суттєво зросли в динаміці відносно інших років.

Проаналізувавши дані табл. 4, можна зазначити, що виробнича собівартість соняшника у 2018 р. значно знизилась (на 45\% порівняно з 2017 р.). Прямі матеріальні витрати поступово за період дослідження зростали, а у 2018 р. стрімко зменшилися (приблизно в 2 рази).

Витрати на насіння та посадковий матеріал найвищими були у 2017 p., a найнижчими - у 2018 р., майже в 2 рази нижче за 2017 р. Витрати на ПММ значно коливалися за досліджуваний період, не маючи чітко вираженої тенденції. Витрати на оплату праці поступово зростали протягом періоду, окрім 2018 р. Інші прямі та загальновиробничі витрати стрімко зростали протягом досліджуваного періоду. Якщо порівнювати останні 2 роки, то вони зросли приблизно на 50\%. 


\section{Таблиця 4}

Структура виробничої собівартості соняшника в АФ «Надія» ТОВ Чугуївського району Харківської області, 2016-2018 pp.

Table 4

Structure of production cost of sunflower at Ltd. «Nadiya» AB of Chuguev district, Kharkiv region, 2016-2018

\begin{tabular}{|l|c|c|c|c|c|c|}
\hline \multirow{2}{*}{ Показник } & \multicolumn{2}{|c|}{2016 p. } & \multicolumn{2}{c|}{2017 p. } & \multicolumn{2}{c|}{2018 p. } \\
\cline { 2 - 7 } & Тис. грн. & $\%$ & Тис. грн. & $\%$ & Тис. грн. & $\%$ \\
\hline $\begin{array}{l}\text { Виробнича собівартість } \\
\text { усього, тис. грн. }\end{array}$ & 5801 & 100 & 5961 & 100 & 3276 & 100 \\
\hline Прямі матеріальні витрати & 5011 & 86,38 & 5099 & 85,54 & 2424 & 73,99 \\
\hline $\begin{array}{l}\text { У т.ч. насіння та посадковий } \\
\text { матеріал }\end{array}$ & 1028 & 17,72 & 1339 & 22,46 & 700 & 21,37 \\
\hline Мінеральні добрива & 2333 & 40,22 & 2619 & 43,94 & 906 & 27,66 \\
\hline ПММ & 214 & 3,69 & 650 & 10,90 & 132 & 4,03 \\
\hline Решта матеріальних витрат & 1136 & 19,58 & 491 & 8,24 & 686 & 20,94 \\
\hline Прямі витрати на оплату праці & 292 & 5,03 & 324 & 5,44 & 8 & 0,24 \\
\hline $\begin{array}{l}\text { Інші прямі витрати та } \\
\text { загальновиробничі витрати - } \\
\text { усього }\end{array}$ & 498 & 8,58 & 538 & 9,03 & 844 & 25,76 \\
\hline Ут.ч. & 392 & 6,76 & 467 & 7,83 & 2 & 0,06 \\
\hline $\begin{array}{l}\text { Амортизація необоротних } \\
\text { активів }\end{array}$ & 106 & 1,83 & 71 & 1,19 & 843 & 25,73 \\
\hline $\begin{array}{l}\text { Відрахування на соціальні } \\
\text { заходи }\end{array}$ & & & & & & \\
\hline
\end{tabular}

Оскільки в господарстві останні роки все більше розвивається галузь тваринництва, доцільно проаналізувати виробничу собівартість продукції тваринництва детальніше - за елементами витрат. Структура виробничої собівартості молока наведена в табл. 5.

\section{Таблиця 5}

Структура виробничої собівартості молока в АФ «Надія» ТОВ Чугуївського району Харківської області, 2016-2018 pp.

Table 5

Structure of milk production cost at Ltd. «Nadiya» AB of Chuguev district, Kharkiv region, 2016-2018

\begin{tabular}{|l|c|c|c|c|c|c|}
\hline \multirow{2}{*}{ Показник } & \multicolumn{2}{|c|}{$2016 \mathrm{p}}$. & \multicolumn{2}{c|}{$2017 \mathrm{p}}$. & \multicolumn{2}{c|}{$2018 \mathrm{p}}$. \\
\cline { 2 - 7 } & Тис. грн. & $\%$ & Тис. грн. & $\%$ & Тис. грн. & $\%$ \\
\hline \multicolumn{1}{|c|}{1} & 2 & 3 & 4 & 5 & 6 & 7 \\
\hline $\begin{array}{l}\text { Виробнича собівартість } \\
\text { усього, тис. грн. }\end{array}$ & 5498,0 & 100,0 & 14019,0 & 100,0 & 41181 & 100,0 \\
\hline Прямі матеріальні витрати & 4158,0 & 75,6 & 11358,0 & 81,0 & 25185 & 61,16 \\
\hline У т.ч. & & & & & & \\
\hline Корми & 2525,0 & 45,9 & 8208,0 & 58,5 & 21944 & 53,29 \\
\hline ПММ & 257,0 & 4,7 & 895,0 & 6,4 & 896 & 2,18 \\
\hline
\end{tabular}


Закінчення таблиці 5

\begin{tabular}{|l|c|c|c|c|c|c|}
\hline \multicolumn{1}{|c|}{1} & 2 & 3 & 4 & 5 & 6 & 7 \\
\hline $\begin{array}{l}\text { Оплата послуг і робіт } \\
\text { сторонніх організацій }\end{array}$ & 55,0 & 1,0 & - & - & & \\
\hline Решта матеріальних витрат & 1321,0 & 24,0 & 2255,0 & 16,1 & 2345 & 5,69 \\
\hline $\begin{array}{l}\text { Прямі витрати на оплату } \\
\text { праці }\end{array}$ & 644,0 & 11,7 & 1529,0 & 10,9 & 3264 & 7,93 \\
\hline $\begin{array}{l}\text { Інші прямі витрати та } \\
\text { загальновиробничі витрати } \\
\text { усього }\end{array}$ & 696,0 & 12,7 & 1132,0 & 8,1 & 12732 & 30,92 \\
\hline Ут.ч. & 462,0 & 8,4 & 807,0 & 5,8 & 311 & 0,76 \\
\hline $\begin{array}{l}\text { Амортизація необоротних } \\
\text { активів }\end{array}$ & 234,0 & 4,3 & 325,0 & 2,3 & 490 & 1,19 \\
\hline $\begin{array}{l}\text { Відрахування на соціальні } \\
\text { заходи }\end{array}$ & - & - & - & - & 10992,0 & 26,69 \\
\hline $\begin{array}{l}\text { Решта ін. прямих та загаль- } \\
\text { новиробничих витрат }\end{array}$ & - & & & & & \\
\hline
\end{tabular}

Аналіз даних табл. 5 свідчить, що найбільша частка в структурі собівартості молока належала витратам на корми - від 45,9\% у 2016 р. (мінімальний показник) до майже 58,5\% - 2017 р. (максимальний показник). Від 7,93\% до 11,7\% у структурі витрат коливаються витрати на оплату праці. Це дуже низький показник. Оплата праці в структурі, за науково обгрунтованими нормами, має становити третину собівартості.

Структура виробничої собівартості іншого важливого виду продукції тваринництва - м'яса ВРХ - наведена в табл. 6.

За даними таблиці спостерігаємо, що найбільша частка в структурі собівартості приросту живої маси ВРX з 2016 р. до 2018 р. включно належала витратам на корми від 37,3\% у 2017 р. до 67,8\% - 2018 р. (максимальний показник). Оплата праці становила $6,8-15 \%$ по різних роках. Це низький показник, але вищий, ніж у структурі собівартості виробництва молока. Сума витрат на приріст живої маси ВРХ у 2018 р. значно зросла порівняно з 2016 р. - у 2,8 раза. Щодо інших матеріальних витрат, то у 2017 р. вони були на першому місці серед витрат (42,6\%), що було пов'язано з покупкою поголів'я ВРХ, a у 2018 р. цей показник склав лише 3,7\%, що є найнижчим показником серед витрат. На другому у 2017 р. - корми - 37,3\% (це найменший показник за досліджуваний період), а ось у 2018 він $є$ найвищим - 67,8\%. 3 двох вищенаведених таблиць можемо зробити висновок, що підприємству варто приділити увагу зростанню рівня витрат на оплату праці.

\section{Таблиця 6}

Структура виробничої собівартості приросту живої маси ВРХ в АФ «Надія» ТОВ Чугуївського району Харківської області, 2016-2018 pp.

Table 6

Structure of production cost of liveweight gain at Ltd. «Nadiya» AB of Chuguev district, Kharkiv region, 2016-2018

\begin{tabular}{|c|c|c|c|c|c|c|}
\hline \multirow{2}{*}{ Показник } & \multicolumn{2}{|c|}{$2016 \mathrm{p}}$. & \multicolumn{2}{c|}{$2017 \mathrm{p}}$. & \multicolumn{2}{c|}{$2018 \mathrm{p.}$} \\
\cline { 2 - 7 } & Тис. грн. & $\%$ & Тис. грн. & $\%$ & Тис. грн. & $\%$ \\
\hline 1 & 2 & 3 & 4 & 5 & 6 & 7 \\
\hline $\begin{array}{l}\text { Виробнича собівартість } \\
\text { усього, тис. грн. }\end{array}$ & 3829,0 & 100,0 & 9614,0 & 100,0 & 11022 & 100,00 \\
\hline
\end{tabular}


Закінчення таблиці 5

\begin{tabular}{|l|c|c|c|c|c|c|}
\hline \multicolumn{1}{|c|}{1} & 2 & 3 & 4 & 5 & 6 & 7 \\
\hline Прямі матеріальні витрати & 2841,0 & 74,2 & 8459,0 & 88,0 & 8453 & 76,69 \\
\hline У т.ч. & & & & & & \\
\hline Корми & 1830,0 & 47,8 & 3589,0 & 37,3 & 7473,0 & 67,80 \\
\hline ПММ & 210,0 & 5,5 & 746,0 & 7,8 & 574,0 & 6,79 \\
\hline $\begin{array}{l}\text { Оплата послуг і робіт } \\
\text { сторонніх організацій }\end{array}$ & 65,0 & 1,7 & 28,0 & 0,3 & - & - \\
\hline Решта матеріальних витрат & 736,0 & 19,2 & 4096,0 & 42,6 & 406,0 & 3,68 \\
\hline $\begin{array}{l}\text { Прямі витрати на оплату } \\
\text { праці }\end{array}$ & 573,0 & 15,0 & 650,0 & 6,8 & 1030 & 9,34 \\
\hline $\begin{array}{l}\text { Інші прямі витрати та } \\
\text { загальновиробничі витрати } \\
\text { усього }\end{array}$ & 415,0 & 10,8 & 505,0 & 5,2 & 1539 & 18,21 \\
\hline У т.ч. & 207,0 & 5,4 & 362,0 & 3,8 & - & - \\
\hline $\begin{array}{l}\text { Амортизація необоротних } \\
\text { активів }\end{array}$ & 208,0 & 5,4 & 143,0 & 1,4 & 222,0 & 2,01 \\
\hline $\begin{array}{l}\text { Відрахування на соціальні } \\
\text { заходи }\end{array}$ & - & - & - & - & 939,0 & 8,52 \\
\hline $\begin{array}{l}\text { Решта ін. прямих та } \\
\text { загальновиробничих витрат }\end{array}$ & & & & & & \\
\hline
\end{tabular}

Створення ефективної системи управління витратами передбачає систематичний моніторинг фактичних витрат, їх поведінку під дією як внутрішніх, так і зовнішніх факторів, прийняття рішення щодо покращення структури собівартості продукції тощо [2].

Зрозуміло, що система управління витратами суттєво відрізняється від традиційного бухгалтерського обліку, орієнтованого на складання фінансової (бухгалтерської) звітності. На відміну від бухгалтерського обліку, який відображає результати діяльності підприємства за минулий період, система управління витратами забезпечує контроль та аналіз поточної діяльності підрозділів, дозволяє виявити взаємозв'язок між рівнем витрат, обсягами виробництва й прибутком і на підставі цього оперативно планувати майбутню діяльність. Тобто за своєю суттю система управління витратами націлена на перспективу.

Система управління витратами направлена на задоволення виключно внутрішніх потреб підприємства при управлінні його виробничо-збутовою діяльністю та $\epsilon$ необмеженою у виборі методів i розробляється відповідно до особливостей організаційної структури, тактичних і стратегічних цілей підприємства, технологій виробництва продукції, вимог виробничих процесів тощо [3].

Дуже складно управляти витратами, а тим більше їх постійно відстежувати. На кінцевий результат виходять тільки у кінці місяця. Щоб можна було відстежувати витрати на будь-якому етапі й у будь-який час, необхідно комп'ютеризувати управління витратами на підприємстві.

Комп'ютеризація обліку витрат на виробництві й калькуляція собівартості продукції вносить істотні корективи в методологію обліку, покликані використати переваги опрацювання даних за допомогою ПЕОМ. Новизна сучасного підходу полягає в органічному взаємозв'язку обліку витрат за видами, місцями виникнення витрат i об’єктами калькуляції, що дозволяє посилити його контрольні функції за рахунок відособлення витрат за місцями їх виникнення. Практично організувати 
диференційований облік витрат, що охоплює як можна більшу кількість місць їх виникнення, у підприємстві вдається лише в умовах автоматизованого збирання й опрацювання інформації.

У міру комп'ютеризації управління і створення автоматизованих виробництв роль нормативного методу зростає. Він переходить в нову якість: створення автоматизованого банку даних дозволяє фіксувати в первинних облікових документах тільки обсяг виконаної роботи й відхилення від норм. Визначення ж сумарного обсягу витрат проводиться на базі інформації, що зберігається в банку даних, обсягу робіт і відхилень від норми. При цьому виключається можливість виникнення помилок, неточностей, приписок та інших перекручень облікової документації.

Практично відпадає потреба в первинних паперових документах, так як відомості про обсяг виконаних робіт і відхилення автоматично фіксуються в ході управління технологічним процесом системою датчиків і реєстраторів. Зростає вірогідність і оперативність облікових даних. Вони уніфікуються, стаючи однаково придатними для всіх видів обліку (виробничого, бухгалтерського, статистичного). Комп'ютеризовані облік і нормативна база стають невід'ємною частиною автоматизованого виробництва, основою господарського розрахунку, сприяють удосконаленню системи в цілому та їі складових.

В умовах автоматизації управління відділи, служби і цехи несуть відповідальність за правильне й своєчасне коригування норм і нормативів у банках даних.

При комп'ютеризації обліку витрат метою вирішення даного завдання $\epsilon$ отримання інформації про динаміку змін норм і нормативів витрат, що впливають на рівень витрат. Оперативне виявлення та поточний облік відхилень від норм витрат (за статтями, місцями виникнення, причинами; особам, відповідальним за відхилення) слід вести за конкретними видами продукції (робіт) або однорідними групами.

Відхиленнями вважається перевитрата або економія, які виявляються порівнянням фактичних витрат 3 нормативними, доплати, викликані організаційнотехнічними неполадками, а також відступу від кошторисів витрат на обслуговування виробництва й управління.

За ступенем повноти виявлення та оформлення документами відхилення від норм поділяють на документовані й недокументовані. До документованих відносять відхилення, які виявляються за даними документів первинного обліку, а також визначаються шляхом розрахунку. Недокументовані відхилення $є$ різницею між загальною сумою відхилення від норм витрат (яка визначається як різниця між фактичними витратами й витратами за нормами) і документованої іiі частини. Зазвичай вони виникають у результаті неточного розрахунку документованих відхилень, незадовільної організації відпуску й заміни сировини та матеріалів, приписок, нестач, втрат, псування матеріалів і продукції, неточного визначення залишків незавершеного виробництва i його оцінювання, застосування неоднакових оцінок при розрахунках нормативів і поточному обліку тощо.

При комп'ютеризації розмір недокументованих відхилень повинен скорочуватися, оскільки отримання інформації автоматизується і поєднується з ходом технологічного процесу й управління (стає їх невід’ємною частиною).

У зв'язку з недостатнім рівнем комп'ютеризації первинного оперативного обліку витрат на виробництво, формування і ведення нормативної бази, іiі локальністю, неспівставністю управлінського (виробничого) й фінансового обліку, вибором облікових одиниць i точністю, оперативно контролювати i регулювати рівень витрат на виробництво дуже важко. Необхідно також, щоб розрахунки, необхідні для управління витратами, були включені в загальну інформаційну, програмну, технічну та організаційну системи управління підприємством. 
Отже, підвищення рівня комп’ютеризації при управлінні витратами на базі використання сучасних технічних засобів збирання, передавання, накопичення, опрацювання та використання інформації на всіх стадіях життєвого циклу товару (послуги) є надзвичайно актуальним питанням.

При підготовці до комп'ютеризації управління будь-яким процесом, у тому числі управління витратами, важливо максимально збільшити кількість комп'ютеризованих задач (розрахунків). При цьому спостерігається тенденція концентрації розрахунків на верхніх рівнях управління, що призводить до їх інформаційного перевантаження й одночасно дефіциту інформації на інших рівнях, а в кінцевому рахунку - до зниження ефективності всієї системи.

3 урахуванням викладеного, необхідно чітко визначати сфери комп'ютеризації управління витратами, для чого всі розрахунки поділяють на два класи завдань:

1. Ті, що потребують першочергової комп’ютеризації.

2. Ti, що вимагають комп'ютеризації в наступну чергу, або взагалі не потребують, або не піддаються комп'ютеризації.

Щоб обгрунтувати віднесення завдань управління витратами до одного із зазначених класів, слід вибрати й обгрунтувати ознаки класифікації.

В якості основних ознак класифікації доцільно приймати:

1. Трудомісткість розрахунків.

2. Вартість розрахунків.

3. Необхідність інформаційного та алгоритмічного сполучення суміжних завдань управління витратами й системи управління підприємства в цілому.

4. Вимоги до оперативності управління витратами та їі відповідності динаміці процесу виробництва й управління в цілому.

5. Точність розрахунків.

6. Можливість реалізації нових завдань управління.

Завдання управління витратами різноманітні, вони вирішуються на підставі великої кількості взаємодіючих, а часом і суперечливих чинників, які породжують безліч різних рішень і схем управління. Застосовувати принцип оптимуму не завжди доцільно через його складності й спеціальні вимоги. Тому при визначенні сфери комп'ютеризації необхідно встановити сфери управління витратами, які потребують першочергової комп'ютеризації, поділити на два підкласи:

1. Ті, що піддаються формалізації й вимагають оптимізації.

2. Ті, що не піддаються формалізації й не потребують оптимізації.

Основна ознака завдань першого підкласу - багатоваріантність. Вибрати найкращий варіант - завдання, яке складно виконати ручними методами розрахунку. Водночас є завдання, які не потребують різноманітних розрахунків.

Висновки. Управління витратами підприємства - це частина єдиного процесу управління підприємством, але в окремому випадку його можна розглядати як самостійну систему, що має свої специфічні особливості, свій критерій управління і включає економіко-правову, організаційно-технічну, економіко-математичну та інформаційну підсистеми. Система управління витратами відіграє ключову роль як в обгрунтуванні управлінських рішень під впливом зовнішнього економічного середовища, так і в налагодженні ефективного внутрішньогосподарського управління та створенні ефективного механізму планування, контролю й аналізу витрат. Перевагами ефективного управління витратами можуть виступати наявність своєчасної, достовірної та повної інформації про собівартість окремих видів продукції та їхні позиції на ринку порівняно $з$ продукцією конкурентів; наявність ресурсів для гнучкого ціноутворення; 
прийняття управлінських рішень із використанням лише релевантної інформації; організація виробництва продукції, конкурентної щодо витрат цін. Крім того, впровадження системи управління витратами допоможе підприємству отримати вищі економічні показники діяльності підприємства.

Conclusions. Enterprise cost management is part of a single enterprise management process, but in a particular case it can be considered as an independent system having its own specific features, its own management criteria and includes economic-legal, organizationaltechnical, economic-mathematical subsystems. The cost management system plays a key role both in the substantiation of management decisions under the influence of the external economic environment, and in establishment of effective internal economy management and creation of effective mechanism for planning, control and analysis of costs. The advantages of effective cost management are the availability of timely, reliable and complete information on the cost of certain types of products and their position in the market compared to the competitors products; availability of resources for flexible pricing; making management decisions using only relevant information; organization of production of products that are competitive in cost. In addition, the introduction of the cost management system contributes to the enterprise higher economic operating rate.

\section{Список використаної літератури}

1. Ціноутворення та нормативні витрати в сільському господарстві / за ред. П. Т. Саблука, Ю. Ф. Мельника, М. В. Зубця, В. Я Месель-Веселяка. Т. 1. Теорія ціноутворення та технологічні карти вирощування сільськогосподарських культур. К., 2008. 698 с.

2. Бондарчук Н. В. Моніторинг виробничих витрат у переробці сільськогосподарських продуктів: автореф. дис. ... на здобуття наук. ступеня канд. екон. наук: спец. 08.07.02. Х., 2014. 20 с.

3. Охріменко I. В. Витрати та собівартість сільськогосподарської продукції в регулюванні економічних відносин сільськогосподарських підприємств: монографія. К.: ННЦ ІАЕ, 2017. 360 с.

\section{References}

1. Tsinoutvorennya ta normatyvni vytraty v sil's'komu hospodarstvi / za red. P. T. Sabluka, YU. F. Mel'nyka, M. V. Zubtsya, V. YA Mesel'-Veselyaka. T. 1. Teoriya tsinoutvorennya ta tekhnolohichni karty vyroshchuvannya sil's'kohospodars'kykh kul'tur. K., 2008. 698 p.

2. Bondarchuk N. V. Monitorynh vyrobnychykh vytrat u pererobtsi sil's'kohospodars'kykh produktiv: avtoref. dys. ... na zdobuttya nauk. stupenya kand. ekon. nauk: spets. 08.07.02. H., 2014. 20 p.

3. Okhrimenko I. V. Costs and cost of agricultural products in the regulation of economic relations of agricultural enterprises: monograph. K.: NNC IAE, 2017. 360 p. 